\title{
KONSEP PENDIDIKAN HUMANIS DALAM PENGEMBANGAN PENDIDIKAN ISLAM
}

\author{
Muh. Idris \\ Jurusan Tarbiyah STAIN Manado \\ Jl. Dr. SH. Sarundajang Kawasan Ringroad I Manado, Sulawesi Utara, 95128 \\ e-mail: idrispasca_uin@yahoo.co.id
}

\begin{abstract}
Abstrak: Tulisan ini mengkaji konsep pendidikan humanis dalam pengembangan pendidikan Islam. Dalam kancah pergulatan global dewasa ini kekhawatiran yang muncul adalah hancurnya rasa kemanusiaan dan terkikisnya semangat religius serta kaburnya nilai-nilai kemanusiaan. Globalisasi menjadikan dunia tampak lebih transparan dan terbuka, yang diibaratkan seperti kehidupan desa yang tidak mengenal jarak. Untuk mengantisipasi hal ini, diperlukan pendidikan humanis dalam pengembangan pendidikan Islam. Penulis berkesimpulan bahwa pendidikan humanis dalam bingkai pendidikan Islam, merupakan suatu sistem pemanusiaan manusia yang unik, mandiri, dan kreatif. Dengan kata lain, memandang manusia sebagai makhluk ciptaan Tuhan dengan potensi yang dimilikinya, dan membangun karakter dalam diri manusia yang menghargai martabat manusia sebagai makhluk yang paling sempurna.
\end{abstract}

\begin{abstract}
The Concept of Humanistic Education in the Development of Islamic Education. This research examines the concept of humanistic education in the development of Islamic education. What is the main concern of today's global struggle is the degrading humanity and diminishing the spirit of religiosity and human values. Globalization turns the world to be more transparent and widely open, which is akin to global village without limited by any boundary. To anticipate this situation, humanistic education is urgently required in Islamic education development. The author concludes that humanistic education in the framework of Islamic education is a unique, independent and creative system of humanizing human. In other words, it views humans as creature of God with all potentials, and construct human character that respect human dignity as being the perfect human creatures.
\end{abstract}

Kata Kunci: pendidikan, humanis, Islam, globalisasi. 


\section{Pendahuluan}

Pendidikan merupakan suatu proses di dalam menemukan transformasi baik dalam diri, maupun komunitas. Oleh karena itu proses pendidikan yang benar adalah membebaskan seseorang dari berbagai kungkungan, intimidasi dan eksploitasi. Pada satu sisi manusia berperan sebagai subjek pendidikan dan pada sisi yang lain sebagai objek pendidikan. Sebagai subjek pendidikan secara moral ia bertanggung jawab melaksanakan misi pendidikan sesuai dengan tujuan dan nilai-nilai yang dikehendaki oleh manusia dimana pendidikan berlangsung. Sebagai objek pendidikan, manusia adalah sebagai sasaran pembinaan dalam melaksanakan proses pendidikan yang pada hakikatnya memiliki pribadi yang sama dengan manusia dewasa.

Pendidikan tidak sekedar mentrasfer ilmu pengetahuan kepada peserta didik, tetapi lebih dari itu mentransfer nilai. Selain itu pendidikan merupakan kerja budaya yang menuntut peserta didik untuk selalu mengembangkan potensi dan daya kreatifitas yang dimilikinya agar tetap survive dalam hidupnya. untuk mencapai tujuan di atas, maka pendidikan humanis adalah salah satu bentuk pendidikan yang harus diterapkan di sebuah lembaga pendidikan.

Pendidikan humanis merupakan suatu sistem pemanusiaan manusia yang unik, mandiri, dan kreatif. Prilaku setiap orang ditentukan oleh orang itu dan memahami manusia terhadap lingkungan dan dirinya sendiri, memandang manusia sebagai manusia yaitu makhluk ciptaan Tuhan dengan fitrah-fitrah tertentu, dan membangun karakter manusia dalam diri manusia yang menghargai harkat dan martabat manusia sebagai makhluk yang paling sempurna.Pendidikan yang mengusung kompetensi/kodrat alam anak didik, bukan dengan "perintah-paksaan," tetapi dengan tuntunan, sehingga menggugah perkembangan kehidupan anak didik baik lahir maupun batin.

\section{Pola Dasar Pendidikan Islam}

Dalam sejarah pendidikan Indonesia maupun dalam studi kependidikan, sebutan pendidikan Islam umumnya dipahami sebatas sebagai "ciri khas" jenis pendidikan yang berlatar belakang keagamaan.Demikian pula batasan yang ditetapkan dalam UndangUndang Nomor 2 Tahun 1989 tentang Sistem Pendidikan Nasional. ${ }^{1}$ Batasan yang sama juga terdapat dalam Undang-Undang Nomor 20 Tahun 2003 tentang Sistem Pendidikan Nasional. $^{2}$

${ }^{1}$ A. Malik Fadjar, Visi Pembaruan Pendidikan Islam (Jakarta: Lembaga Pengembangan Pendidikan dan Penyusunan Naskah Indonesia, 1998), h. 3. Lihat juga A. Malik Fadjar,"Pengembangan Pendidikan Islam yang Menjanjikan Masa Depan"dalam Edukasi Vol. 2, Nomor 1, JanuariMaret 2004

${ }^{2}$ Pada pasal 30 bagian kesembilan ayat 4 dijelaskan bahwa pendidikan keagamaan berbentuk pendidikan diniyah, Pesantren, pasraman, pabhaja samanera, dan bentuk lain yang sejenis. Lihat Undang-Undang Nomor 20 Tahun 2003 tentang Sistem pendidikan Nasional, h. 14 
Zarkowi Soejoeti sebagaimana yang dikutip oleh A.Malik Fadjar mengemukakan bahwa Pendidikan Islam paling tidak mempunyai tiga pengertian. Pertama, lembaga pendidikan Islam itu pendirian dan penyelenggaraannya didorong oleh hasrat mengejewantahkan nilai-nilai Islam yang tercermin dalam nama lembaga pendidikan itu dan kegiatan-kegiatan yang diselenggarakan. Dalam pengertian ini Islam dilihat sebagai sumber nilai yang harus diwujudkan dalam kehidupan lembaga pendidikan yang bersangkutan. Kedua, lembaga pendidikan yang memberikan perhatian dan yang menyelenggarakan kajian tentang Islam yang tercermin dalam program kajian sebagai ilmu dan diperlakukan sebagai ilmu-ilmu lain yang menjadi program kajian lembaga pendidikan Islam yang bersangkutan. Ketiga, mengandung dua pengertian di atas dalam arti lembaga tersebut memperlakukan Islam sebagai sumber nilai bagi sikap dan tingkah laku yang harus tercermin dalam penyelenggaraannya maupun sebagai bidang kajian yang tercermin dalam program kajiannya. ${ }^{3}$

Konsep pendidikan Islam tersebut di atas belum memadai secara falsafi untuk disebut sebagai pendidikan Islam, tetapi dapat dijadikan sebagai pengantar dalam memahami pendidikan Islam secara lebih mendasar. ${ }^{4}$ Berdasarkan pengertian ini maka keberadaan pendidikan Islam tidak sekedar menyangkut persoalan ciri khas, melainkan lebih mendasar lagi yaitu tujuan yang diidamkan dan diyakini sebagai yang paling ideal yaitu insân kâmil atau muslim paripurna. ${ }^{5}$

Tujuan ini sekaligus mempertegas bahwa misi dan tanggung jawab yang diemban pendidikan Islam lebih berat lagi.Dalam pembicaraan ini jenis dan pengertian pendidikan Islam mencakup ketiga-tiganya, karena memang ketiga-tiganya itu yang selama ini tumbuh serta berkembang di Indonesia dan sudah menjadi bagian yang tidak terpisahkan dari sejarah maupun kebijakan pendidikan secara nasional.Bahkan tidak berlebihan kalau secara politis dikatakan bahwa kehadiran dan keberadaannya merupakan bagian dari andil umat Islam dalam perjuangan maupun dalam mengisi kemerdekaan. ${ }^{6}$

\section{Tujuan Pendidikan Islam}

Azyumardi Azra berpendapat bahwa banyak yang bisa dijual dari Islam, termasuk aspek disiplin, kerja keras, keadilan, demokrasi, musawarah, HAM, perdamaian dan semacamnya ${ }^{7}$. Orang Islam percaya bahwa Islam adalah rậmatan lil 'âlamîn. Oleh karena itu pendidikan

${ }^{3}$ A.Malik Fadjar, Pidato Pengukuhan Guru Besar, "Pengembangan Pendidikan Islam yang Menjanjikan Masa Depan", dalam Muhammad In'am Esha dan Helmi Syaifuddin (ed.) Kumpulan Orasi Ilmiah Pengukuhan Guru Besar UIN Malang Periode 1989-2006 (Malang: UIN Malang Press, 2006), h. 144-145. Lihat juga Fadjar,'Pengembangan Pendidikan Islam"dalam Jurnal Edukasi Volume 2, Nomor 1, Januari-Maret 2004.

${ }^{4}$ A. Malik Fadjar, Reorientasi Pendidikan Islam (Jakarta: Fajar Dunia, 1999), h. 31.

${ }^{5}$ Fadjar, Visi Pembaruan, h. 4.

${ }^{6}$ Fadjar, Visi Pembaruan, h. 4.

7Azyumardi Azra, Islam Subtantif: AgarUmat Tidak Jadi Buih (Bandung: Mizan, 2000), h. 132. 
Islam bertujuan menciptakan insân kâmil. Terbinanya kepribadian muslim atau insân kâmil yang merupakan ketetapan tujuan pendidikan Islam masih merupakan idea statis. Namun kualitasnya dinamis dan berkembang nilai-nilainya. Tujuan pendidikan Islam itu sarat dengan nilai-nilai fundamental yang memungkinkan terwujudnya kepribadian muslim atau insân kâmil yaitu yang kondisi fisik dan mentalnya merupakan satu kesatuan secara terpadu. Sehingga dalam penampilan dan kegiatannya tidak terjadi dikotomi antara jasmani dan rohani, duniawi dan ukhrawi. ${ }^{8}$

Untuk membentuk peserta didik yang memiliki kepribadian paripurna, maka eksistensi pendidikan agama merupakan sebuah kemestian yang harus diajarkan, meskipun pada sekolah-sekolah umum. Namun demikian dalam dataran operasional prosesnya tidak hanya dilakukan sebatas mentransfer ilmu pengetahuan, tetapi jauh lebih penting adalah bagaimana ilmu yang mereka peroleh mampu membuahkan suatu sikap yang baik sesuai dengan pesan nilai ilmu yang dimilikinya. ${ }^{9}$

Al-Ghazâlî sebagaimana yang dikutip oleh Fathiyah Hasan Sulaiman menyatakan bahwa tujuan umum pendidikan Islam tercermin dalam dua segi yaitu: insan purna yang bertujuan mendekatkan diri kepada Allah dan insan purna yang bertujuan mendapatkan kebahagiaan hidup di dunia dan di akhirat.Kebahagiaan di dunia dan akhirat dalam pandangan al-Ghazâlî adalah menempatkan kebahagiaan dalam proporsi yang sebenarnya. Kebahagiaan yang lebih memiliki nilai universal, abadi, dan lebih hakiki itulah yang diprioritaskan. ${ }^{10}$

Terbinanya kepribadian Muslim ini menurut A.Malik Fadjar nampak pada diri K.H Ahmad Dahlan (1868-1923) yang mencita-citakan pendidikan yang memberikan kedamaian yang diselenggarakannya dengan a) baik budi dalam agama, b) luas pandangan, dan c) bersedia berjuang untuk kemajuan masyarakat. Dengan perkataan lain bahwa perwujudan pendidikan Islam K.H Ahmad Dahlan mengacu pada tiga matra yang saling terkait, yaitu: 1). Tauhid yang akan mendudukkan harkat manusia sebagai insân ah sani taqwîm, punya daya tahan terhadap segala ujian hidup dan siap memihak kepada kebenaran. 2). Jiwa dan pandangan hidup Islam yang akan membawa cita rah̆matan lil âlamîn.3). Kemajuan yang akan menempatkan manusia hidup kreatif. ${ }^{11}$

Pandangan ini sejalan dengan pengertian pendidikan Islam yang dikemukakan oleh Muhammad Munir Mursi yang menyatakan bahwa pendidikan Islam adalah pendidikan

${ }^{8}$ A. Malik Fadjar, "Mencari Dasar Filosofi Pendidikan Islam; Sebuah Tinjauan Terhadap Pendidikan Kemuhammadiyahan dan Al-Islam, dalam Imron Nasri dan A. Hasan Kunio, (ed.), Di Seputar Percakapan Pendidikan Dalam Muhammadiyah (Yogyakarta: Pustaka SM, 1994), h. 21-22.

${ }^{9}$ Hamka, Lembaga Hidup (Jakarta: Djajamurni, 1962), h. 204. Lihat juga Hamka, Tafsir al-Azhar (Jakarta: Pustaka Panjimas, 1998), Juz I, h. 170. Lihat juga Hamka, Lembaga Budi (Jakarta: Pustaka Panjimas, 1983), h. 2-3.

${ }^{10}$ Fathiyah Hasan Sulaiman, Sistem Pendidikan Versi al-Ghazâlî, terj. Fathur Rahman (Bandung: al-Ma'arif, 1986), h. 24.

${ }^{11}$ Fadjar, "Mencari Dasar Filosofi Pendidikan Islam," h. 22. 
fitrah manusia, karena Islam adalah agama fitrah, maka segala perintah, larangan, dan kepatuhannya dapat mengantarkan mengetahui fitrah itu. ${ }^{12}$ Pendidikan yang baik adalah pendidikan yang dalam prosesnya mampu mengembangkan seluruh fitrah peserta didik terutama fitrah akal dan agamanya. Dengan fitrah ini peserta didik akan dapat mengembangkan daya berpikir secara rasional. Sementara melalui fitrah agama, akan tertanam pilar-pilar kebaikan pada diri peserta didik yang kemudian terimplikasi dalam seluruh aktifitas hidupnya. ${ }^{13}$

Berkaitan dengan tujuan pendidikan Islam, Athiyah al-Abrasyi menyimpulkan lima tujuan yang asasi yaitu: untuk membantu pembentukan akhlak yang mulia, mempersiapkan kehidupan dunia dan akhirat, persiapan untuk mencari rezki dan menjaga kemaslahatan, menumbuhkan ruh ilmiah pada anak didik dan memenuhi rasa keingintahuannya serta memungkinkan untuk mengkaji berbagai ilmu, menyiapkan anak didik untuk menguasai profesi tertentu. ${ }^{14} \mathrm{Di}$ samping itu dengan pendidikan, seseorang dimungkinkan mengenal diri dan alam sekitarnya. ${ }^{15}$

Al-Kailani menyatakan bahwa pendidikan Islam berorientasi pada kelangsungan eksistensi manusia dan juga peningkatan harkat kemanusiaannya. ${ }^{16}$ Sedangkan menurut al-Nahlawi tujuan pendidikan Islam adalah pembebasan dan penyelamatan anak didik. ${ }^{17}$ Sehingga ia dapat mengenal agama baik secara teori maupun prakteknya. ${ }^{18}$ Sementara itu Muhammad 'Abduh menjelaskan bahwa tujuan pendidikan adalah mendidik akal dan jiwa dan menyampaikannya kepada batas-batas kemungkinan seseorang mencapai kebahagiaan hidup di dunia dan akhirat. ${ }^{19}$ Dari rumusan ini dapat diketahui bahwa tujuan pendidikan yang ingin dicapai oleh Muhammad 'Abduh adalah tujuan yang luas, mencakup aspek akal dan aspek spiritual.Tujuan pendidikan tersebut diprediksi dalam rangka pencapaian hasil. ${ }^{20}$

\footnotetext{
${ }^{12}$ Muhammad Munir Mursi, al-Tarbiyah al-Islâmiyah Ushûluha wa Tathawwuriha fi alBilâd al-Arabiyah (Kairo: Dâr al-Kutub, 1977), h. 25.

${ }^{13}$ Muhammad 'Abduh, "Al-Madâris al-Tajhizât wa al-Madâris al-'Âliyât" dalam 'Imârah, al-A'mâl al-Kâmil Li al-Imâm Muhammad Abduh (Bairut: al-Muassasah al-'Arabiyah li al-Dirâsah wa al-Nashr, 1972), Juz III, h. 117.

${ }^{14}$ Muhammad Athiyah al-Abrasyi, Al-Tarbiyah al-Islâmiyah wa Falsafatuha (Kairo: Isa alBâbi al-Halabi, 1969), h. 37

${ }^{15}$ Muhammad Athiyah al-Abrasyi, Al-Ittijahat al-Hadîtsah fi al-Tarbiyah (Mesir: Isa alBabi al-Halabi, t.th), h. 263.

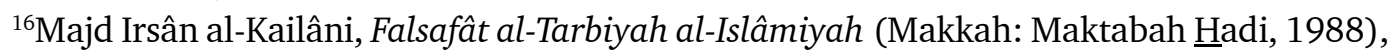
h. 83.

17'Abdurrahman al-Nahlawi, Ushûl al-Tarbiyah al-Islâmiyah fi al-Bait wa al-Madrasah wa al-Mujtama' (Damaskus: Dâr al-Fikr, 1996), h. 20.

${ }^{18}$ Ahmad Fu'ad al-Ahwani, Al-Tarbiyah fi al-Islâm (Kairo: Dâr al-Ma'ârif, t.th), h. 97.

${ }^{19}$ Muhammad Rasyd Ridha, Târkh al-Ustâdz al-Imâm al-Syaikh Muhammad 'Abduh (Mesir: al-Manâr, 1931), Jilid II, h. 17.

${ }^{20} \mathrm{Jum}$ C. Nunnalli, Educational Mesurement and Evaluation(New York: Hill Book Company, t.t.), h. 16. Bandingkan pula Remmers, et al., A.Practical Introduction to Mesurement and Evaluation (New York: Brothers Publisher,t.th), h. 172.
} 
Pendidikan perlu menjadi bekal demi kesiapan manusia untuk memahamikeberagaman manifestasi nilai-nilai dalam peri kehidupannya sebagai anggotamasyarakat. Peserta didik harus diperkenalkan ke berbagai bidang.Perkenalan itu akhirnya membuka perspektif bagi seseorang untuk membuat pilihan, apakah ia ingin menjadi homo religiosus, homo aestheticus, homo politicus, homo economicus, homo academicus, dan sebagainya. ${ }^{21}$

Pendidikan Islam mempunyai beberapa karakteristik, yaitu: Pertama, penekanan pada pencarian ilmu pengetahuan, penguasaan dan pengembangan atas dasar ibadah kepada Allah. Kedua, pengakuan akan potensi dan kemampuan seseorang untuk berkembang dalam suatu kepribadian, setiap pencari ilmu dipandang sebagai makhluk Tuhan yang perlu dihormati dan disantuni, agar potensi-potensi yang dimilikinya dapat teraktualisasi dengan sebaik-baiknya. Ketiga, pengamalan ilmu pengetahuan atas dasar tanggung jawab kepada Tuhan dan masyarakat manusia.Di sini pengetahuan bukan hanya untuk diketahui dan dikembangkan, tetapi sekaligus dipraktekkan dalam kehidupan nyata. Dengan demikian terdapat konsistensi antara apa-apa yang diketahui dengan pengamalannya dalam kehidupan sehari-hari. ${ }^{22}$

\section{Globalisasi}

Memperhatikan perkembangan kehidupan manusia akhir-akhir ini dapat ditarik benang merahnya bahwa manusia kini berada pada kesadaran sejarah yang paling puncak, yakni kesadaran bahwa dirinya sebagai bagian tak terpisahkan dari kehidupan manusia lain secara universal.Meskipun kesadaran ini merupakan bagian dari kemanusiaan semenjak keberadaannya di dunia, tapi pada saat inilah kesadaran tersebut menemukan momentum yang tepat, dan sekaligus tantangan yang dahsyat.

Kemajuan ilmu pengetahuan dan teknologi seperti transportasi, komunikasi, dan komputer, telah menjadikan kesadaran tersebut teraktualisasikan dengan "sempurna," setidaknya secara material. Saat ini manusia dengan begitu mudah dan cepatnya berkomunikasi dengan manusia lain meskipun dari sisi tempat sangat berjauhan. Manusia bisa menyaksikan peristiwa di belahan dunia secara cepat dan bahkan seketika itu pula.Para ilmuwan menyebut fenomena ini dengan globalisasi (globalization).Globalisasidalam konteks ilmu-ilmu sosial menjadi diskursus yang menarik. Hal ini bisa dilihat dari beragamnya kerangka pandang teoretis mengenai globalisasi. Marshall McLuhann, misalnya, seorang pakar komunikasi yang mempunyai pengaruh sangat luas, menawarkan konsep the global village. Di Indonesia

\footnotetext{
${ }^{21}$ Hassan, "Pendidikan adalah Pembudayaan", dalam Widiastono, ed., Pendidikan Manusia Indonesia, h. 64.

${ }^{22}$ Azyumardi Azra, Pendidikan Islam Tradisi dan Modernisasi Menuju Milenium Baru (Jakarta: Logos Wacana Ilmu, 1999), h. 10. Lihat juga Azyumardi Azra, Esai-Esai Intelektual Muslim \& Pendidikan Islam (Jakarta: Logos Wacana Ilmu, 1998), h. 12-14.
} 
konsep ini diistilahkan dengan "desa buana." Dunia diibaratkan seperti kehidupan desa yang tidak mengenal jarak. ${ }^{23}$

Terdapat banyak berkah yang bisa ditimba dari globalisasi sekaligus memunculkan keprihatinan dan gugatan atas berbagai negatif yang ditimbulkan. Terutama berkenaan dengan pengaruh budaya luar yang berpotensi memarginalkan, bahkan mematikan budaya lokal yang dipercaya mengandung kearifan tradisional (traditional wisdom). ${ }^{24}$

Secara normatif, Islam telah memberikan landasan kuat bagi pelaksanaan pendidikan. Pertama, Islam menekankan bahwa pendidikan merupakan kewajiban agama dimana proses pembelajaran dan transmisi Ilmu sangat bermakna bagi kehidupan manusia. Inilah latar belakang turun wahyu pertama dengan perintah membaca, menulis, dan mengajar, Kedua, seluruh rangkaian pelaksanaan pendidikan adalah ibadah kepada Allah Swt. Sebagai sebuah ibadah, maka pendidikan merupakan kewajiban individual sekaligus kolektif. Ketiga, Islam memberikan derajat yang tinggi bagi kaum terdidik, sarjana maupun ilmuwan,.Keempat, Islam memberikan landasan bahwa pendidikan merupakan aktivitassepanjang hayat,(long life education). Kelima, konstruksi pendidikan menurut Islam bersifat dialogis, inovatif dan terbuka dalam menerima ilmu pengetahuan baik dari Timur maupun Barat. Itulah sebabnya Nabi Muhammad saw memerintahkan umatnya menuntut ilmu walau ke negeri Cina. ${ }^{25}$ Kesadaran akan pentingnya pendidikan dengan landasan konseptual-normatif inilah yang menyebabkan warisan khazanah intelektual Islam sejak zaman Nabi hingga abad pertengahan mencapai kejayaan global.

Untuk menggambarkankondisi kejayaan Islam yang disinyalir terjadi antara abad 7-11 M dengan figur Muhammad saw sebagai modelling mampu merubah karakteristik jahili ahlArab menuju masyarakat yang berbudaya. ${ }^{26}$ Prestasi besar peradaban Islam saat itu merupakan keberhasilan yang ditopang pengembangkan penalaran yang luarbiasa. ${ }^{27}$ Dengan luasnya wawasan dan cakrawala pandang manusia maka tingkat nilai-nilai kemanusiaannya cenderung lebih akomodatif.

\footnotetext{
${ }^{23}$ Fadjar, Holistika, h.169. Lihat pula, Mahmud Hamdi Zaqzuq, Reposisi Islam di Era Globalisasi, terj. Abdullah Hakam Shah(Yogyakarta: Pelangi Aksara, 2004), h.5-6.

${ }^{24}$ Fadjar, Holistika, h.169. Bandingkan pula, Tidak ada kebaikan pada kebanyakan bisikan mereka kecuali dari orang yang menyuruh (manusia) memberi sedekah, atau berbuat ma'ruf, atau mengadakan perdamaian di antara manusia..." (Q.S. al-Nisa' 114). Azhar Arsyad, "Peranan Pendidikan Rohani Dalam Mewujudkan Perdamaian Dunia" dalam Azhar Arsyad (Ed), Islam dan Perdamaian Global (Yogyakarta: Madyan Press, 2002), h.166. Bandingkan juga, Margareth Smith, Pemikiran dan Doktrin Mistis Imam Ghazali, terj. Amrouni (Jakarta: Riora Cipta, 2000), h. 167.

${ }^{25} \mathrm{http}: / / w w w . b r u d e r f i c . o r . i d / h-60 /$ pendidikan-yang-humanis.html. Tanggal 17 Desember 2007. 2007.

${ }^{26} \mathrm{http}: / /$ www.sfeduresearch.org/content/view/175/66/1/6/lang,id/. Tanggal, 17 Desember

${ }^{27}$ http://www.bruderfic.or.id/h-60/pendidikan-yang-humanis.html. Tanggal 17 Desember 2007 Lihat pula,.htp://www.sfeduresearch.org/content/view/175/66/1/6/lang,id/. Tanggal, 17 Desember 2007.
} 
Ali Syari'ati sebagaimana dikutip Fadjar menjelaskan tentang atribut yang melekat pada diri manusia yang membedakannya dengan binatang, yaitu kesadaran diri, kemauan bebas, dan kreativitas. ${ }^{28}$ Tiga ciri fundamental ini menjadi pembeda manusia dengan binatang dalam dimensinya sebagai insân bukan sebagaibasyar.Jika sebagai basyar manusia berpotensi untuk terikat pada struktur fisiologis dan realitas empiris yang mengitarinya, maka sebagai insân manusia dengan kesadaran diri, kemauan bebas, dan kreativitasnya dapat melakukan "pengembaraan" dalam membangun kebudayaan dan peradaban.

\section{Pendidikan Humanis}

Pendidikan Islam mempunyai peran strategis sebagai sarana human resources dan human investment.Artinya, pendidikan selain bertujuan menumbuh kembangkan kehidupan yang lebih baik, juga telah ikut mewarnai dan menjadi landasan moral dan etik sebagai perekat nilai kemanusiaan dalam pemberdayaan jati diri bangsa. ${ }^{29}$ Berangkat dari arti penting pendidikan ini, maka wajar jika hakekat pendidikan merupakan proses humanisasi.

Humanisasi dipandang sebagai sebuah gagasan positif oleh kebanyakan orang. Dengan kentalnya persaudaraan sesorang cenderung dipahami sebagai sikap humanisme. Humanisme mengingatkan kita akan gagasan-gagasan seperti kecintaan akan peri kemanusiaan, perdamaian, dan persaudaraan. Tetapi, makna filosofis dari humanisme jauh lebih signifikan; humanisme adalah cara berpikir bahwa mengemukakan konsep peri kemanusiaan sebagai fokus dan satu-satunya. tujuan. Humanisme sebagai sebuah sistem pemikiran yang berdasarkan pada berbagai nilai, karakteristik, dan tindak tanduk yang dipercaya terbaik bagi manusia, bukannya pada otoritas supernatural manapun. ${ }^{30}$

Pendidikan merupakan proses humanisasi atau pemanusiaan manusia. ${ }^{31}$ Suatu pandangan yang mengimplikasikan proses kependidikan dengan berorientasi kepada pengembangan aspek-aspek kemanusiaan manusia, baik secara fisik-biologis maupun ruhaniah-psikologis. Aspek fisik-biologis manusia dengan sendirinya akan mengalami perkembangan, pertumbuhan, dan "penuaan." Sedangkan aspek ruhaniah-psikologis manusia melalui pendidikan dicoba "didewasakan," disadarkan, dan "di-insânkâmil-kan" melalui pendidikan sebagai elemen yang berpretensi positif dalam pembangunan kehidupan yang berkeadaban. ${ }^{22}$ Dari pemikiran

\footnotetext{
${ }^{28}$ Fadjar, Holistika, h.182. Lihat pula, Paulo Freire, Pedagogi Pengharapan: Menghayati Kembali Pedagogi Kaum Tertindas, terj. A.Widya Martaya (Yogyakarta: Kanisius, 2001), h.66. Bandingkan juga Leonard Binder, Islamic Liberalism: a Critique of Development Ideilogis (London: Chicago Press, 1988), h. 233.

${ }^{29} \mathrm{http}: / /$ www.sfeduresearch.org/content/view/175/66/1/6/lang,id/. Tanggal, 17 Desember 2007.

${ }^{30} \mathrm{http}: / /$ www.sfeduresearch.org/content/view/175/66/1/6/lang,id/, tanggal 17 Desember 2007. Kajian Normatif Teks al-Qur'an tentang Humanis.

${ }^{31}$ Fadjar, Holistika, h.181. Lihat juga Fadjar, Tinta Yang Tidak Pernah Habis, h. 152.

${ }^{32}$ http://www.sfeduresearch.org/content/view/175/66/1/6/lang,id/. Tanggal, 17 Desember 2007.
} 
ini maka pendidikan merupakan tindakan sadar dengan tujuan memelihara dan mengembangkan fitrah serta potensi (sumber daya) manusia menuju terbentuknya manusia seutuhnya.

Pemahaman terhadap konsep pendidikan sebagai proses humanisasi adalah melakukan penyadaran terhadap manusia sebagai peserta didik mengenai kedudukannya dan perannya dalam kehidupan ini. Kata penyadaran jelas mengandung makna dan implikasi yang mendasar karena akan bersentuhan dengan aspek yang paling dalam dari kehidupan manusia, yaitu dinamika kejiwaan dan kerohanian. Dua aspek inilah yang menjadi pendorong manusia dalam membangun kehidupan yang berkebudayaan dan peradaban. ${ }^{33}$

Manusia adalah makhluk multidimensional yang dapat ditelaah dari berbagai sudut pandang. Eduart Spranger (1950), melihat manusia sebagai makhluk jasmani dan rohani. Yang membedakan manusia dengan makhluk lain adalah aspek kerohaniannya. Manusia akan menjadi sungguh-sungguh manusia kalau ia mengembangkan nilai-nilai rohani (nilai-nilai budaya) yang meliputi: nilai pengetahuan, keagamaan, kesenian, ekonomi, kemasyarakatan dan politik. ${ }^{34}$

Kecerdasan inter dan intra personal ini selanjutnya oleh Daniel Goleman (1995) disebut dengan kecerdasan emosional. Ternyata pula bahwa sebagian besar kegiatan kecerdasan logis matematis dan kecerdasan verbal bahasa dilakukan dibelahan otak kiri.Sedangkan kegiatan kecerdasan lainnya dilakukan pada otak kanan (intra personal, interpersonal, visual-ruang, gerak-badan, dan musik-ritme). ${ }^{35}$

Desain pendidikan yang mengacu kepada pembebasan, humanisasi, penyadaran, dan kreativitas, sesungguhnya sejak awal telah digagas oleh Ki Hajar Dewantara ${ }^{36}$ dan K. H. Ahmad Dahlan. ${ }^{37}$ Ki Hajar Dewantara, misalnya, tidak saja memiliki gagasan yang cerdas

${ }^{33}$ Fadjar, Tinta, h. 152.

${ }^{34}$ http://www.bruderfic.or.id/h-60/pendidikan-yang-humanis.html. Tanggal 17 Desember 2007.

${ }^{35}$ http://www.bruderfic.or.id/h-60/pendidikan-yang-humanis.html. Tanggal 17 Desember 2007.

${ }^{36}$ Tokoh Ki Hajar- Dewantara dalam lembaga Perguruan Taman Siswa merupakan lambang dari kemampuan Bangsa Indonesia, kemampuan nasional, untuk mengurus dirinya sendiri dalam bidang pendidikan.Perguruan Taman Siswa dalam kesadaran banyak orang merupakan lambang yang paling nyata dari kemandirian, kemerdekaan jiwa Bangsa Indonesia ketika meng-hadapi suatu tatanan sosial politik kolonial yang dipaksakan kepada dirinya.Perguruan Taman Siswa selama kehidupannya dalam zaman kolonial Belanda dapat dipandang sebagai suatu kekuatan pendidikan yang dimiliki Bangsa Indonesia dalam perjuangan politiknya melawan pemerintah Hindia Belanda.BS. Mardiatmadja, "Ruh Pendidikan," dalam Tonny D.Widiastono, Pendidikan Manusia Indonesia (Jakarta: Kompas, 2004), h. 76. Bandingkan pula, Mochtar Buchori, Pendidikan Dalam pembangunan (Yogyakarta: IKIP Muhammadiyah Jakarta Press, 1994), h.1-3.

${ }^{37}$ Sosok K. H. Ahmad Dahlan (1868-1923) adalah pribadi yang kaya akan gagasan pembaruan pendidikan dengan "mengadaptasi" pendidikan modern Barat sejauh membawa kemajuan bagi umat Islam khususnya dan Indonesia secara umum. Kejelian dan kecerdasan K. H. Ahmad Dahlan sedikitnya tampak pada gagasan integrasi antara normativitas ajaran Islam dan historisitas konsep pendidikan Barat, antara pendidikan agama dan pendidikan umum yang sebelumnya 
pada zamannya, tetapi juga tetap aktual di zaman sekarang. Dia menekankan praktik pendidikan yang mengusung kompetensi/kodrat alam anak didik, bukan dengan "perintahpaksaan," tetapi dengan tuntunan, sehingga menggugah perkembangan kehidupan anak didik baik lahir maupun batin.

Cara mendidik seperti ini dikenal dengan pendekatan among. Ada dua hal yang mendasari adanya pendekatan tersebut. Pertama, kemerdekaan sebagai syarat untuk menghidupkan dan menggerakkan kekuatan lahir maupun batin, hingga dapat hidup merdeka. Kedua, kodrat alam sebagai syarat untuk menghidupkan dan mencapai kemajuan dengan secepat-cepatnya dan sebaik-baiknya. ${ }^{38}$

Berangkat dari kenyataan masih lebarnya jurang perbedaan antara tuntutan dunia abad ke-21 akan kualitas kemampuan intelektual dan profesional serta sikap, kepribadian, dan moral manusia Indonesia pada umumnya dengan kemampuan dan sikap manusia Indonesia pada umumnya agar Indonesia dapat mendudukkan diri secara bermartabat dalam masyarakat dunia di era globalisasi ini. Pendidikan Islam dan pembangunan kebudayaan harus mampu menyelenggarakan dan menciptakan proses pendidikan atau suasana pendidikan yang dapat mengembangkan dan membudayakan kemampuan, sikap, kepribadian dan watak yang humanis dalam menghadapi persaingan dan tantangan zaman. Hanya dengan pendidikan yang relevan dan bermutu maka Islam akan mampu mengembangkan IPTEK dan kebudayaan serta mewujudkan masyarakat yang maju, demokratis, berbudaya, adil dan makmur dalam bingkai pendidikan Islam. ${ }^{39}$

Olehkarena itu, teman sebaya adalah pendidik yang kerap kali berdayaguna dan berhasil guna di masyarakat. Sudah sejak masa kecil, apalagi masa remaja dan sampai ke alam dewasa, teman sebaya amat penting dalam proses kehidupan. Sebab pendidikan terbaik masuk ke hati sanubari seseorang dengan teman sebaya, amat sering mengenali sampai lahir-batin. Teman sebaya juga yang dapat mengenali dengan lebih baik dibanding orang lain, nilai-nilai yang sungguh dijunjung tinggi seseorang, bukan hanya "dikatakan dijun-jung tinggi". Teman sebaya dapat ditemukan dalam lingkungan pergaulan seorang manusia, sejak kecil sampai dewasa.Mereka ini ada dalam keluarga, yaitu kakak-adik. Mereka juga ada dalam lingkungan sekolah, di kampung, dalam organisasi, atau dalam lingkup pekerjaan dan lembaga keagamaan. Sekarang terbuka kemungkinan untuk memperoleh teman sebaya melalui radio dan televisi serta internet. Hampir tidak terbatas potret untuk memperoleh teman sebaya, yang berpengaruh baik maupun buruk.

dipandang sebagai sesuatu yang bertentangan. Fadjar, Holistika, h. 183. lihat pula, Azyumardi Azra, Menuju Masyarakat Madani: Gagasan Fakta dan Tantangan (Bandung: Remaja Rosdakarya, 1999), h. 107-108.

${ }^{38}$ Fadjar, Holistika, h.183. Lihat juga Fadjar, Tinta, h. 156. Lihat pula, Winarno Surakhman, Reformasi Pendidikan Muhammadiyah Suatu Keniscayaan (Yogyakarta: Pustaka Suara Muhammadiyah, 2003).

${ }^{39}$ Soedijarto, Pendidikan Nasional sebagai Wahana Mencerdasakan Kehidupan Bangsa dan Membangun Peradaban Negara-Bangsa: Sebuah Usaha Memahami Makna UUD’ 45, h. 90. 
Apabila seseorang sudah dapat memahami, menghayati, dan mengamalkan nilainilai dasar manusia, teman sebaya dapat menyaji-kan rekan-tanding atau rekan-renung yang meningkatkan mutu atau mendalamkan peresapan nilai untuk diintegrasikan ke dalam diri manusia. Dalam hidup sehari-hari pengaruh teman sebaya terwujud secara "sambil jalan", tanpa rencana dan tanpa evaluasi ketat. Dalam berbagai lembaga pendidikan, pengaruh itu dapat diorganisasikan. Pengaruh itu dapat dengan mencolok kelihatan di sekolah, dalam organisasi Karang Taruna, dalam perkumpulan orang muda atau olah raga, dan dalam persaudaraan lembaga keagamaan.Pengaruh teman sebaya ini dapat dipahami karena terlaksana tidak sebagai instruksi atau pelajaran yang kaku, tetapi dalam mengalami hidup.Kecuali itu, teman sebaya tidak mendikte dan tidak memerintah, mereka mengakui kesetaraan siapa pun yang ada dalam persaudaraan atau persahabatan. Iklim kesetaraan itu mengundang simpati dan simpati itu mempermudah orang menemukan nilai, menghayati makna hidup serta mengembangkan sikap saling menghargai. Semua itu menyuburkan nilai. $^{40}$

Dari titik pandang sosio-antropologis, kekhasan manusia yang membedakannya dengan makhluk lain adalah bahwa manusia itu berbudaya, sedangkan makhluk lainnya tidak berbudaya. Maka salah satu cara yang efektif untuk menjadikan manusia lebih manusiawi adalah dengan mengembangkan kebudayaannya. Persoalannya budaya dalam masyarakat itu berbeda-beda. Dalam masalah kebudayaan berlaku pepatah:"Lain ladang lain belalang, lain lubuk lain ikannya." Manusia akan benar-benar menjadi manusia kalau ia hidup dalam budayanya sendiri. Manusia yang seutuhnya antara lain dimengerti sebagai manusia itu sendiri ditambah dengan budaya masyarakat yang melingkupinya. Proses pendewasaan dan penyadaran dalam konteks pendidikan ini mengandung makna yang mendasar, karena bersentuhan dengan aspek paling dalam dari kehidupan manusia, yaitu kejiwaan dan keruhanian; sebagai dua elemen yang berpretensi positif bagi "manusia utuh" adalah manusia sebagai subjek. Sebaliknya, manusia yang hanya beradaptasi adalah manusia sebagai objek. Adaptasi merupakan bentuk pertahanan diri yang paling rapuh. Seseorang menyesuaikan diri karena ia tidak mampu mengubah realitas. Menyesuaikan diri adalah kekhasan tingkah laku binatang yang bila diperlihatkan oleh manusia akan merupakan gejala dehumanisasi. ${ }^{41}$

Pendidikan dengan tekanan pada transfer ilmu dan keahlian daripada pembangunan moralitas akan memunculkan sikap individualistik, skeptik, enggan menerima hal-hal non--observasional dan sikap menjauhi nilai-nilai Ilahiyah yang bernuansa kemanusiaan. Akibat lebih jauh, model pendidikan ini akan menghasilkan manusia mekanistik yang mengabaikan penghargaan kemanusiaan yang jauh dari nilai imajinatif, kreatif dan kultural. Kenyataan inilah yang menyebabkan kearifan, kecerdasan spiritual, kesadaran

\footnotetext{
${ }^{40}$ BS. Mardiatmadja, "Ruh Pendidikan", dalam Widiastono, Pendidikan, h. 76.

${ }^{41}$ http://www.sfeduresearch.org/content/view/175/66/1/6/lang,id/. Tanggal 17 Desember 2007.
} 
manusia terhadap makna hidup, lingkungan social dan alamnya menjadi gagal tumbuh dan akhirnya akan mati dan menciptakan ketegangan kemanusian seperti konflik dan perang, krisis nilai etis, dislokasi, alienasi, kekosongan nilai rohaniah dan sebagainya.

Untuk itu, pendidikan Islam harus mampu mengantarkan manusia menuju kesempurnaan dan kelengkapan nilai kemanusiaan dalam arti yang sesungguhnya sebagai suatu sistem pemanusiawian manusia yang unik, mandiri dan kreatif sebagaimana fungsi diturunkannya al-Quran sebagai petunjuk bagi manusia dan penjelas bagi petunjuk itu serta pembeda antara yang benar dan yang salah. Al-Qur'an berperan dalam meluruskan kegagalan sistem pendidikan yang terjebak pada proses dehumanisasi.

Pendidikan Humanis yang dieksplorasi di dalam Islam adalah memanusiakan manusia sesuai dengan perannya sebagai khalifah di bumi ini. Manusia merupakan makhluk yang sempurna. Kelebihan manusia dibandingkan dengan makhluk lainnya yaitu dari mulai proses penciptaannya (Q.S. al-Sajdah/32:7-9, al-Insân/76: 2-3), bentuknya (Q.S. al-Tn/ 95:4) serta tugas yang diberikan kepada manusia sebagai khalifah di muka bumi (Q.S. al-Baqarah/2:30-34, al-An'âm/6:165) dan sebagai makhluk yang wajib untuk mengabdi kepada Allah (Q.S. al-Dzâriyat/51:56).

Begitu tingginya derajat manusia, maka dalam pandangan Islam manusia harus menggunakan potensi yang diberikan Allah kepadanya untuk mengembangkan dirinya baik dengan panca indera, akal maupun hatinya sehingga benar-benar menjadi manusia seutuhnya.

Pendidikan yang benar adalah suatu usaha pembinaan pribadi manusia untuk mencapai tujuan akhirnya (perilaku hubungan dengan Tuhan dan diri sendiri) dan sekaligus untuk kepentingan masyarakat (perilaku hubungan dengan diri sendiri, keluarga, masyarakat dan alam sekitarnya). Secara singkat dikatakan bahwa pendidikan nilai adalah suatu proses dimana seseorang menemukan maknanya sebagai pribadi pada saat dimana nilai-nilai tertentu memberikan arti pada jalan hidupnya. Proses ini menyangkut "perjalanan menuju ke kedalaman diri sendiri", menyentuh bagian-bagian terdalam diri manusia, seperti daya refleksi, introspeksi, analisa dan kemampuan menemukan diri sendiri dan betapa besar harga dirinya. Pendidikan nilai menyangkut ranah daya cipta, rasa dan karsa, menyentuh seluruh pengalaman seseorang. ${ }^{42}$

Pendekatan pembelajaran humanis memandang manusia sebagai subjek yang bebas merdeka untuk menentukan arah hidupnya. Manusia bertanggung jawab penuh atas hidupnya sendiri dan juga atas hidup orang lain. Pendekatan yang lebih tepat digunakan dalam pembelajaran yang humanis adalah pendekatan dialogis, reflektif, dan ekspresif yang mengajak peserta didik untuk berpikir bersama secara kritis dan kreatif. Pendidik bertindak sebagai fasilitator dan partner dialog; pendekatan reflektif mengajak peserta

\footnotetext{
${ }^{42}$ http://www.bruderfic.or.id/h-60/pendidikan-yang-humanis.html. Tanggal 17 Desember 2007
} 
didik untuk berdialog dengan dirinya sendiri; sedangkan pendekatan ekspresif mengajak peserta didik untuk mengekspresikan diri dengan segala potensinya (realisasi dan aktulisasi diri).

Dengan demikian pendidik tidak mengambil alih tangung jawab, melainkan sekedar membantu dan mendampingi peserta didik dalam proses perkembangan diri, penentuan sikap dan pemilahan nilai-nilai yang akan diperjuangkannya Namun, dengan menyadari watak eksistensial manusia yang selalu bergantung pada realitas primordialnya, seperti budaya peradaban, dan agama, keprihatinan seperti di atas bisa dibenarkan.

Agar manusia di satu sisi tidak tercerabut dari realitas primordialnya itu, dan di sisi lain, manusia mau tidak mau harus berhadapan dengan kemajuan budaya danperadaban yang perlu direspon, maka sikap moderat, atau menjadi ummatan wasathan dalam istilah Q.S. Al-Baqarah/2: 143, perlu dikembangkan. Seperti dikatakan Paulo Freire, manusia harus bisa "mengada" atau bereksistensi(to exist), tidak sekadar hidup(to live)di dunia. Freire menekankan pentingnya hidup secara dinamis. Namun begitu, Freire juga menekankan integrasi dalamkehidupan ini, yaitu kemampuan menyesuaikan diri dengan realitas dan kemampuan kritis untuk membuat pilihan dan mengubah realitas. ${ }^{43}$ Menurut A.Malik Fadjar nampaknya Freire ingin memberikan suatu afirmasi filosofis bahwa manusia pada dasarnya merupakan makhluk yang mempunyai kemerdekaan, sehingga manusia pada hakikatnya mampu melakukan transendensi dengan semua realitas yang mengitarinya. ${ }^{44}$

Pendidikan saat ini mempunyai landasan yang lebih realistis dan strategis dengan telah disahkannya Undang-Undang Nomor 20 Tahun 2003 tentang Sistem Pendidikan Nasional. Dengan keluarnya UU ini tidak berarti masalah pendidikan serta-merta teratasi. Kita masih harus bekerja keras dalam berbagai sektor pendidikan untuk menfungsikan pendidikan nasional dengan baik agar kita dapat mencapai tujuan seperti yang dirumuskan dalam undang-undang tersebut pada Bab II, Pasal 3, yang berbunyi, "Pendidikan nasional berfungsi mengembangkan kemampuan dan membentuk watak serta peradaban bangsa yang bermartabat dalam rangka mencerdaskan kehidupan bangsa, bertujuan untuk berkembangnya potensi peserta didik agar menjadi manusia yang beriman dan bertakwa kepada Tuhan Yang Maha Esa, berakhlak mulia, sehat, berilmu, cakap, kreatif, mandiri, dan menjadi warga negara yang demokratis serta bertanggung jawab". ${ }^{45}$

Membangun sikap demokratis, dinamis, dan kritis bukanlah hal mudah, sebab perkembangan kehidupan sendiri penuh dengan teka-teki paradoksal seperti globalisasi. Globalisasi di satu sisi bisa memunculkan fenomena universal civilization dan sisi lain bisa membangkitkan kesadaran akademik lokal. ${ }^{46}$ Analisis yang mendalam dikemukakan

${ }^{43}$ Fadjar, Holistika, h.170. Lihat pula, Hasbi Indra, Pendidikan Islam Melawan Globalisasi (Jakarta: Ridamulia, 2005), h. 125-126.

${ }^{44}$ Fadjar, Tinta, h. 153.

${ }^{45}$ Undang-Undang Nomor 20 Tahun 2003 tentang Sistem pendidikan Nasional.

${ }^{46}$ Fadjar, Holistika, h.170. 
oleh Huntington, sebagaimana yang diungkapkan oleh A. Malik Fadjar, menjadikan identitas budaya dan peradaban sebagai persoalan yang sangat penting dalam kehidupan manusia yang kini telah mengalami proses globalisasi. Persoalan yang dimaksud Huntington adalah terjadinya konflik di sepanjang garis pemisah budaya(culture fault lines) yang memisahkan peradaban-peradaban seperti Barat, Konfusius, Jepang, Islam, Hindu, Ortodoks, Slavic, Amerika Latin, dan Afrika. Huntington tampaknya berkeyakinan bahwa budaya akan menjadi sumber fundamental konflik di dunia setelah sebelumnya dipengaruhi oleh perbedaan ideologi dan ekonomi.

Huntington mengajukan sedikitnya enam alasan utama kenapa konflik atau benturan dapat terjadi. ${ }^{47}$ Pertama, perbedaan antar peradaban tak hanya rill, tapi juga mendasar. Peradaban terdiferensiasi oleh sejarah, bahasa, budaya, tradisi, dan yang lebih penting adalah agama. Perbedaan-perbedaan iniselama berabad-abad telah menimbulkan konflik. Kedua, dunia sekarang semakin menyempit. Interaksi antara orang-orang atau bangsabangsa yang berbeda peradabannya semakin meningkatkan kesadaran-kesadaran mereka untuk memperkokoh identitas, yang pada gilirannya memperkuat perbedaan dan kebencian yang merentang atau dipandang merentang jauh ke belakang dalam sejarah. Ketiga, proses modernisasi ekonomi dan perubahan sosial dunia membuat orang atau masyarakat tercerabut dari identitas lokal mereka yang sudah mengakar dengan kuat, di samping memperlemah negara-bangsa sebagai sumber identitas mereka. Keempat, tumbuhnya kesadaran peradaban dimungkinkan karena peran ganda Barat. Di satu sisi Barat berada di puncak kekuatan,namun di sisi lain, dan ini akibat posisi Barat tersebut,yaitu kembalinya ke fenomena asal, sedang berlangsung diantara peradaban-peradaban non-Barat. Kelima, karakteristik dan perbedaan budaya kurang bisa menyatu dan karena itu kurang bisa berkompromi antara karakteristik dan perbedaan politik dan ekonomi. Keenam, regionalisme ekonomi semakin meningkat. Blok-blok ekonomi regional tampaknya terus meningkat pada masa yang akan datang. ${ }^{48}$

Menurut Huntington, bahwa konflik atau benturan peradaban (clash of civilization) yang dilatarbelakangi oleh keenam faktor di atas, berlangsung pada dua tingkatan. Pada tingkat mikro, kelompok-kelompok yang berdekatan sepanjang garis pemisah di antara peradaban-peradaban sering kali berjuang dengan kekerasan untuk saling menguasai perbatasan masing-masing. Sedang pada tingkat makro, negara-negara yang mempunyai peradaban yang berbeda-beda bersaing untuk merebut kekuasaan ekonomi dan militer,

${ }^{47}$ A. Malik Fadjar, "Demokrasi dalam Konteks Indonesia Baru", butir-butir bahan ceramah disampaikan pada sidang Tanwir I Pemuda Muhammadiyah Balik Papan, 12 Januari 1999, dalam Himpunan Pidato Menteri Agama RI., Tahun, 1999, disusun olehBiro Hukum dan Humas Sekretaris Jenderal Departemen Agama RI.

${ }^{48}$ Fadjar, Holistika, h.173. Lihat pula, Azymardi Azra, Konflik Baru Antar Peradaban: Globalisasi, Radikalisme dan Pluralisme (Jakarta: RajaGrafindo Persada, 2002), h. 17. Bandingkan juga, Saiful Mujani et al. Benturan Peradaban: Sikap dan Perilaku Islamis Indonesia terhadap Amerika Serikat (Jakarta: Nalar, 2005). 
berjuang untuk menguasai lembaga-lembaga internasional dan pihak-pihak ketiga, dan bersaing mempromosikan nilai-nilai agama dan politik mereka.

Dalam konteks Indonesia, tesis Huntington itu agak sulit dicari evidensi empiriknya, terutama jika dikaitkan dengan dua level pertentangan peradaban di atas. Namun jika memperhatikan modus konflik sosial yang terjadi di tanah air akhir-akhir ini, bisa dikatakan bahwa sebenarnya benturan kini telah terjadi, meskipun masih berada pada level lokal atau marginal. Misalnya, benturan yang disebabkan oleh perbedaan etnis dan keagamaan, maupun yang disebabkan menajamenya fragmentasi sosial sebagai warisan sejarah sebelumnya yang disebabkan oleh kesalahan manajemen dalam perencanaan dan pelaksanaan pembangunan nasional.

Semua konflik yang datang secara bertubi-tubi memunculkan kegetiran terhadap masa depan bangsa ini yang dalam rentang waktu lama disatukan oleh suatu ikatan kebangsaan yang luhur. Yang paling ironis, agama yang seharusnya dapat menjadi perekat sosial (societal glue), nyatanya malah terperangkap dalam berbagai konflik. Padahal agama, apa pun namanya, sejatinya sama-sama mempunyai misi suci dan agung, yakni (salah satunya) menciptakan kedamaian universal sehingga manusia dapat menikmati kebahagiaan esensialnya di dunia dan di akhirat kelak. Agama dalam konteks mikro, sebenarnya dapat diperankan secara positif-konstruktif dalam mempertahankan dan sekaligus mengembangkan keutuhan bangsa Indonesia yang ditandai dengan keanekaragaman dan kemajemukan. Sekadar contoh, di bawah ini akan dikemukakan beberapa nukilan nuktah-nuktah normatif agama Islam yang memiliki kaitan dengan persoalan keanekaragaman dan kemajemukan, multikulturalisme dan pluralisme, dan solusi integrasi keduanya. ${ }^{49}$

Untuk mengakomodasi benturan peradaban menuju pendidikan yang humanis adalah dengan jalan meningkatkan kualitas kehidupan beragama sehingga tidak terjadi sikap fanatik, feodalis dan fundamentalis. Sikap beragama seperti ini disebabkan karena: Pertama, cara beragama masyarakat yang masih berorientasi ke "dalam," sebagai pemahaman yang dangkal terhadap apa yang dipandang mempunyai nilai otoritatif dan kemutlakan dalam agama.

Keberagamaan seperti ini dalam istilah psikologi agama disebut dengan gaya hidup keagamaan otoritatif (religion of authority). Agama mana pun memang menyandarkan pada suatu otoritas mutlak yang hadir melalui nilai dan semangat keagamaannya. Seharusnya cara beragama lebih membuka diri, dan menjalin komunikasi beragama ke luar sehingga akan membuka pentilasi kehidupan beragama.Dengan demikian, suasana beragama lebih ramah dan dinamis.

Kedua, dengan sikap keberagamaan yang berorintasi lokal-feodalistik belum menasional dan global seperti di atas, maka agama mudah dimanfaatkan untuk mem-blow up isu-isu di

${ }^{49}$ Fadjar, Holistika, h. 173. 
luar dunia keagamaan yang tengah mengemuka, seperti kesenjangan atau fragmentasi sosial..$^{50}$

Model tampilan keberagamaan tersebut, menyebabkan gagalnya suatu penghayatan agama karena yang esensial dari beragama tidak tertangkap dan tidak terungkap. ${ }^{51}$ Kita perlu prihatin sebab sebagian peristiwa kerusuhan massa marak belakangan ini menurut sebuah sinyalemen, karena terjadinya manipulasi simbol-simbol agama yang dilakukan oleh pihak-pihak tertentu hanya untuk meraih kepentingan sesaat. Padahal agama dalam kehidupan berfungsi sebagai perekat dalam menata tatanan sosial yang sangat damai, humanis dan anggun. ${ }^{52}$

\section{Penutup}

Pendidikan humanis memandang manusia sebagai manusia, yaitu sebagai makhluk ciptaan Tuhan dengan fithrah-fithrah tertentu. Manusia yang manusiawi yang dihasilkan oleh pendidikan yang humanis diharapkan bisa berfikir, merasa, berkemauan, dan bertindak sesuai dengan nilai-nilai luhur kemanusiaan yang bisa mengganti sifat individualistik, egoistik, egosentrik dengan sifat kasih sayang sesama manusia, sifat ingin memberi dan menerima, sifat saling menolong, sifat ingin mencari kesamaan, dan lain sebagainya.

Pendidikan humanis dalam bingkai pendidikan Islam, merupakan suatu sistem pemanusiaan manusia yang unik, mandiri, dan kreatif. Memandang manusia sebagai manusia yaitu makhluk ciptaan Tuhan dengan fitrah-fitrah tertentu, dan membangun karakter manusia dalam diri manusia yang menghargai harkat dan martabat manusia sebagai makhluk yang paling sempurna. Maka hak setiap individu hendaknya dihormati; pendidikan hendaknya membantu peserta didik untuk menjadi merdeka dan independen secara fisik, mental dan spiritual; pendidikan hendaknya memperkaya setiap individu dengan tetapmempertimbangkanperbedaan antara masing-masing pribadi.

\section{Pustaka Acuan}

'Abduh, Muhammad, "Al-Madâris al-Tajhizât wa al-Madâris al-Aliyât," dalam Imarah, al-A'mâl al-Kâmil Li al-Imâm Muhammad 'Abduh.Bairut: al-Muassasah al-Arabiyah li al-Dirâsah wa al-Nashr, 1972, Juz III.

Al-Abrasyi,Muhammad Athiyah. Al-Ittijahât al-Hadîtsah fi al-Tarbiyah. Mesir: Isa al-Bâbi al- $\underline{\text { Halabi, t.t.. }}$

${ }^{50}$ Ibid., h.174-175.

${ }^{51}$ A.Malik Fadjar, Visi Pembaruan Pendidikan Islam(Jakarta: LP3NI), 1998), h. 186-187.

${ }^{52}$ Muh. Idris, "Pentingnya Pendidikan Agama terhadap Kesehatan Mental," dalam Foramadiahi, Vol. 2 No. 1 Tahun 2006. Lihat juga Muh. Idris, et al., "Liberalisme Islam (Studi Kasus Pemikiran Jaringan Islam Liberal)," dalam Bahtiar Effendy dan Soetrisno Hadi, Agama dan Radikalisme di Indonesia (Jakarta: Nuqtah, 2007), h. 77. 
Al-Abrasyi,Muhammad Athiyah. Ruh al-Tarbiyah wa al-Ta'lim.t.t.p: Dar Ihya' al-Kutub alArabiyah, t.th.

Al-Ahwani, Ahmad Fu'ad. Al-Tarbiyah fi al-Islâm. Kairo: Dar al-Ma'arif, t.th.

Arsyad, Azhar. "Peranan Pendidikan Rohani Dalam Mewujudkan Perdamaian Dunia" dalam Azhar Arsyad (ed.). Islam dan Perdamaian Global.Yogyakarta: Madyan Press, 2002.

Azra, Azymardi. Konflik Baru Antar Peradaban: Globalisasi, Radikalisme dan Pluralisme. Jakarta: RajaGrafindo Persada, 2002.

Azra, Azymardi. Esai-Esai Intelektual Muslim \& Pendidikan Islam.Jakarta: Logos Wacana Ilmu, 1998.

Azra, Azymardi. Islam Subtantif: Agar Umat Tidak Jadi Buih. Bandung: Mizan, 2000.

Azra, Azymardi. Menuju Masyarakat Madani: Gagasan Fakta dan Tantangan. Bandung: Remaja Rosdakarya, 1999.

Azra, Azymardi. Pendidikan Islam Tradisi dan Modernisasi Menuju Milenium Baru. Jakarta: Logos Wacana Ilmu, 1999.

Binder, Leonard. Islamic Liberalism: A Critique of Development Ideilogis. London: Chicago Press, 1988.

BS.Mardiatmadja, "Ruh Pendidikan" dalam Tonny D.Widiastono.Pendidikan Manusia Indonesia. Jakarta: Kompas, 2004.

Buchori, Mochtar. Pendidikan Dalam pembangunan, Yogyakarta: IKIP Muhammadiyah Jakarta Press. 1994.

C. Nunnalli, Jum. Educational Mesurement and Evaluation. New York: Hill Book Company, t.t. Al-Dn,'Abd al-Asr Syams. Al-Mazhab al-Tarbawi 'Inda Ibn Jamâ‘ah. Bairut: Dâr IqraÊ, 1983.

Fadjar, A. Malik. Reorientasi Pandidikan Islam. Jakarata: Fajar Dunia, 1999

Fadjar, A. Malik. "Demokrasi dalam Konteks Indonesia Baru", butir-butir bahan ceramah disampaikan pada sidang Tanwir I Pemuda Muhammadiyah Balik Papan, 12 Januari 1999, dalam Himpunan Pidato Menteri Agama RI., Tahun, 1999, disusun olehBiro Hukum dan Humas Sekretaris Jenderal Departemen Agama RI.

Fadjar, A. Malik. "Mencari Dasar Filosofi Pendidikan Islam; Sebuah Tinjauan Terhadap Pendidikan Kemuhammadiyahan dan Al-Islam, dalam Imron Nasri dan A. Hasan Kunio, (ed.).Di Seputar Percakapan Pendidikan Dalam Muhammadiyah. Yogyakarta: Pustaka SM, 1994.

Fadjar, A. Malik. Visi Pembaruan Pendidikan Islam. Jakarta: Lembaga Pengembangan Pendidikan dan Penyusunan Naskah Indonesia, 1998.

Fadjar, A. Malik. "Pengembangan Pendidikan Islam yang Menjanjikan Masa Depan" dalam Jurnal Edukasi Volume 2, Nomor 1, Januari-Maret 2004.

Freire, Paulo. Pedagogi Pengharapan: Menghayati Kembali Pedagogi Kaum Tertindas, terj. A.Widya Martaya. Yogyakarta: Kanisius, 2001.

Hamka. Lembaga Budi.Jakarta: Pustaka Panjimas, 1983. 
MIQOT Vol. XXXVIII No. 2 Juli-Desember 2014

Hamka. Lembaga Hidup. Jakarta: Djajamurni, 1962.

Hamka. Tafsir al-Azhar.Jakarta: Pustaka Panjimas, 1998, Juz I.

Idris, Muh. Pentingnya Pendidikan Agama terhadap Kesehatan Mental, Foramadiahi.Vol. 2 No. 1 Tahun 2006.

Idris, Muh. Et al. "Liberalisme Islam (Studi Kasus Pemikiran Jaringan Islam Liberal)," dalam Bahtiar Effendy dan Soetrisno Hadi, Agama dan Radikalisme di Indonesia. Jakarta: Nuqtah, 2007.

Indra, Hasbi. Pendidikan Islam Melawan Globalisasi. Jakarta: Ridamulia, 2005.

Al-Kailani, Majid Irsan. Falsafât al-Tarbiyah al- Islâmiyah. Makkah: Maktabah Hadi, 1988.

Mujani, Saiful et al. Benturan Peradaban: Sikap dan Perilaku Islamis Indonesia terhadap Amerika Serikat. Jakarta: Nalar, 2005.

Mursi, Muhammad Munir. Al-Tarbiyah al-Islâmiyah Ushûluha wa Tathawwuriha fi al-Bilâd al-Arabiyah. Kairo: Dar al-Kutub, 1977.

Muthawa', Ibrahim Ashmat.Ushûl al-Tarbiyah.t.t.: Dâr al-Ma'ârif, t.t.

Al-Nahlawi,Abdurrahman. Ushûl al-Tarbiyah al-Islâmiyah fî al-Bait wa al-Madrasah wa al-MujtamaÊ. Damaskus: Dâr al-Fikr, 1996.

Pratiknya, Ahmad Watik, "Identifikasi Masalah Pendidikan Agama Islam di Indonesia", dalam Muslih Usa, (ed.).Pendidikan Islam di Indonesia antara Cita dan Fakta. Yogyakarta: PT Tiara Wacana, 1991.

Remmers, et.al., A Practical Introduction to Mesurement and Evaluation.New York: Brothers Publisher, t.t.

Ridha, Muhammad Rasyd. Târikh al-Ustâzd al-Imâm al-Syaikh Muhammad ÊAbduh. Mesir: al-Manar, 1931, Jilid II

S.Brumbaugh, Robert dan Nathaniel M. Lawrence.Six Essay on The Foundations of Western Thought. Boston: Houghton Mifflin Company, 1963

Smith, Margareth. Pemikiran dan Doktrin Mistis Imam Ghazali, terj. Amroeni Jakarta: Riora Cipta, 2000.

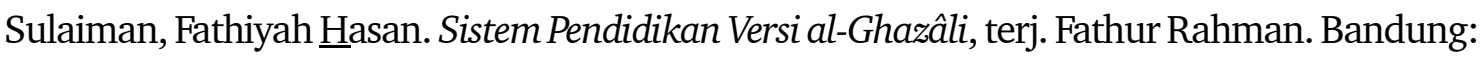
al-Ma'arif, 1986.

Surakhman, Winarno. Reformasi Pendidikan Muhammadiyah Suatu Keniscayaan. Yogyakarta: Pustaka Suara Muhammadiyah, 2003.

Syahatah, Hasan. Talîm al-Dîn al-Islâmi baina al-Nazhariyah wa al-Tathbq.Kairo: Maktabah al-Dâr al-Arabiyah, 1994

Tafsir, Ahmad. Ilmu Pendidikan Dalam Perspektif Islam. Bandung: PT Remaja Rosda Karya, 1994.

Undang-Undang Nomor 20 Tahun 2003 tentang Sistem pendidikan Nasional

Zaqzuq, Mahmud Hamdi. Reposisi Islam di Era Globalisasi, terj. Abdullah Hakam Shah. Yogyakarta: Pelangi Aksara, 2004. 